\title{
Machinability of nickel-based superalloys using ceramic tools
}

\author{
Anton Seleznev ${ }^{1 *}$, Nestor Washington Solis Pinargote ${ }^{2}$, Anton Smirnov ${ }^{2 *}$
}

${ }^{1}$ Spark Plasma Sintering Research Laboratory, Moscow State University of Technology “STANKIN", Vadkovsky per. 1, Moscow 127055, Russia; a.seleznev@stankin.ru (A.S.)

${ }^{2}$ Laboratory of 3D Structural and Functional Engineering, Moscow State University of Technology "STANKIN", Vadkovsky per. 1, 127055 Moscow, Russia; nw.solis@stankin.ru (N.W.S.P.), a.smirnov@stankin.ru (A.S.)

* Correspondence: a.seleznev@stankin.ru (A.S.); a.smirnov@stankin.ru (A.S.); Tel.: +7-4999-7323-70 (A.S. \& A.S.)

\begin{abstract}
Nickel-based superalloys are attractive to many industrial sectors (automotive, military, energy, aerospace etc.). However, their physical properties make them difficult to machining using traditional tools. Therefore, the new materials for the machining of Nibased alloys are required. Ceramic-based composites could act as a tool to replace the current materials. The incentives for this paper are to provide an overview of existing ceramic composites and draw some conclusions that will help in solving the problem of choosing materials for processing of Ni-based superalloys. Despite the diversity of ceramic composites in this work the focus was on the SiAlON ceramic.
\end{abstract}

Keywords: nickel-based superalloys; ceramic instruments; carbides; cubic boron nitride; cermet; SiAlON

\section{Introduction}

Superalloys show high strength, corrosion or oxidation resistance at elevated temperatures, and creep resistance [1-4]. The most classic type of the superalloy is nickel-based superalloys are mainly used for aerospace, oil and gas mining, petrochemical, and other industrial sectors [5-7]. Table 1 presents various categories, compositions and properties of nickelbased superalloys [8]. 
Table 1. Various categories, compositions and properties of nickel-based superalloys. 


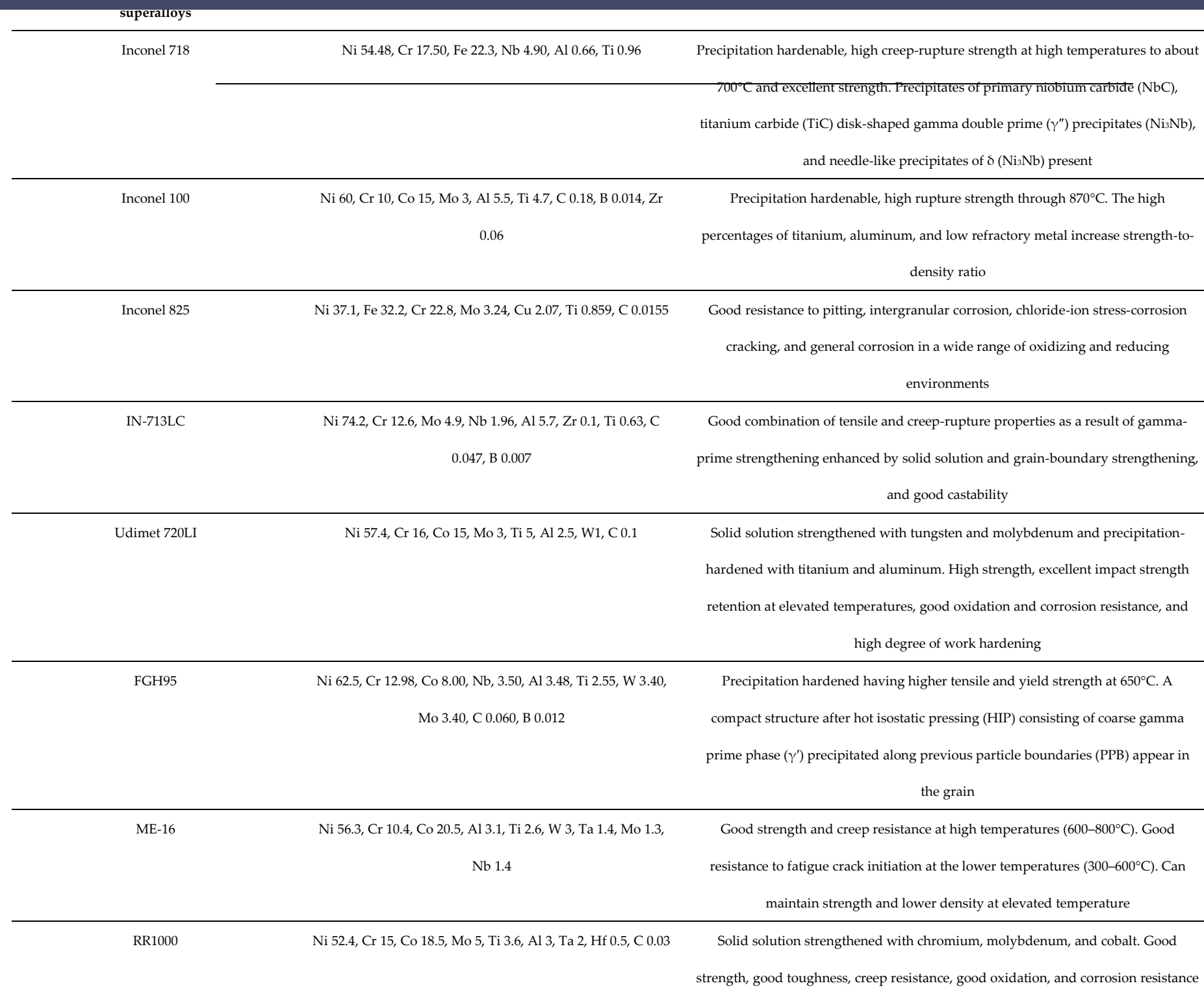

at high temperature

Nimonic C-263 Ni 51.0, Cr 20.0, Co 20.0, Mo 5.8, Ti 2.2, Al 0.5

A readily weldable, age-hardenable superalloy with excellent strength, ductility, and corrosion resistance up to around $850^{\circ} \mathrm{C}$. Molybdenum for solid-solution strengthening

Nimonic $105 \quad$ Ni 54.0, Co 20.0, Cr 15.0, Mo 5.0, Al 4.7, Ti 1.3
An age-hardenable superalloy within creased aluminum for improved oxidation-resistance and strength, and high creep-rupture properties up to around $950^{\circ} \mathrm{C}$. Strengthened by additions of molybdenum, aluminum, and titanium
Nimonic 75
Ni 80.5, Cr 19.5

Nimonic 80 A Ni 76.0, Cr 19.5, Ti 2.4, Al 1.4

Good corrosion and heat resistance, high-temperature strength, and outstanding oxidation-resistance
An age-hardenable creep-resistant alloy for service at temperatures up to around $815^{\circ} \mathrm{C}$ 
Hastelloy alloy C-2000
Ni 47, Cr 22, Fe 18, Mo 9, Co 1.5, W 0.6
Localized corrosion resistance, good resistance to hot acids, and excellent resistance to stress-corrosion cracking
Ni 57, Cr 20, Co 10, Mo 8.5, Ti 2.1, Al

1.5, Fe 1.5, Mn 0.3, Si 0.15, C 0.06, B

However, despite the exceptional properties of Ni-based superalloys, the problem of machining continues of exist due to their high strength and plastic viscosity [9-11]. There is a series of problems relating to conventional machining of $\mathrm{Ni}$ based superalloys including the following:

- Due to the low thermal conductivity, the heat generated during processing is not transferred to the chips or the workpiece, but is concentrated on the cutting edges, which leads to crater wear and extensive plastic strain of the cutting tool edge.

- Increased crater wear results in catastrophic failure of cutting instrument and plastic strain causes high cutting forces.

- Metal pick-up and coating delamination due to chemical reaction of Ni-based superalloys during machining reduces tool life.

- High abrasive wear on the cutting edge of the tool because of the presence of hard and abrasive intermetallic compounds in the microstructure of these alloys.

- Changes in the microstructure of the alloys due to high heat generation during machining and generated residual stresses cause a further reduction in the fatigue life of the component.

- In addition, the machining of these alloys also leads to high cutting emulsion consumption, cost of which corresponds to cost of cutting instruments [12].

Based on the above-listed drawbacks the manufacturers are interested in minimizing the losses at all stages in the processing chain. Therefore, new tool materials or other technical solutions for Ni-based superalloys machining are needed. Use of ceramics as a cutting tool could be proposed as a possible solution to these challenges.

Ceramic tool materials exhibit very high hardness and wear resistance, high resistance to plastic deformation, and chemical stability. The diversity of ceramic tool grades appearing each year on the market indicates that these materials are promising. Ceramic tools used for broad range of materials and processing operations, including also high-speed finishing machining of superalloys.

The most promising group of ceramic materials for machining of Ni-based superalloys is mixed nitride and oxide ceramic, namely SiAlON. In our previous article we provided basic information about this type of materials. Briefly, SiAlONs are formed when silicon nitride $\left(\mathrm{Si}_{3} \mathrm{~N}_{4}\right)$, aluminum oxide $\left(\mathrm{Al}_{2} \mathrm{O}_{3}\right)$, and aluminum nitride (AlN) react together. $\alpha$-SiAlON and $\beta$-SiAlON represent the two main phases of this 
type of ceramic. Each phase features its own properties, which can be contributed to the composites [13].

This review paper provides an overview of ceramic tools for machining of nickel-based superalloys including effect of cutting parameters, using of coolant supply and the integrity of machined surface. Special attention was focused on SiAlON ceramic as the currently most promising candidate for the processing of these alloys.

\section{Type of tool materials for machining nickel-based al- loys}

It should be noted in the analysis of publication activity over the last 20-30 years the growing interest of the scientific community to the use of effective solutions for the treatment of heat-resistant nickel-based alloys.

By increasing efficiency, researchers basically mean an increase in cutting conditions (cutting speed, feed) without losing the quality of the machined surface.

Usually, the authors distinguish 3 groups of tool materials that are applicable for processing nickel-based alloys:

- carbide - representing the interaction of tungsten carbide (WC) / titanium carbide (TiC) / tantalum carbide $(\mathrm{TaC})$ and a binder component - cobalt (Co) including those with wear-resistant PVD / CVD nitride or carbonitride multilayer coatings [14-16];

- boron nitride having to the cubic structure $(\mathrm{CBN})$ [17];

- ceramic instruments are solid solutions of variable composition formed on the basis of $\mathrm{Al}_{2} \mathrm{O}_{3}$ or $\mathrm{Si}_{3} \mathrm{~N}_{4}$ [18-24]. Next, consider the details of each of them.

\subsection{Carbide for machining nickel-based alloys}

The use as a cutting tool of carbide when processing nickel-based HRSA due to their high ratio of hardness, tensile strength and fracture toughness [25].

R. Arunachalam et al. [26] observed that the basic research of physical and mechanical, chemical and performance properties of carbide instruments during turning and milling of various structural materials, including difficult-began at the turn of 70s - 80s 20th century [27]. In addition, it is noted that these studies have not been interrupted and are being conducted now. Prolonged and systematic research carbide instruments allowed to use this tool in the industry in the processing of nickel-based HRSA cutting as the main material.

Koseki S. et al. [28] performed a comprehensive analysis of damage analysis of carbide instruments with commercial TiN PVD-coated at turning Ni-based superalloy (Inconel 718) [21]. Electron probe microanalysis (EPMA), scanning electron microscopy (SEM) and transmission electron microscopy (TEM) analyzes showed that the treated material is mechanically adhered to the tool, but there are no chemical bonds. 
These facts confirm the absence diffusive and oxidative deterioration. The authors noted that the development of extended wear in places of micro-defects in the form of pores and voids in the coating. Thus, it is necessary to lowest such defects.

Zihua Hu et al. [29] suggested using the rake face chemical-mechanical polishing (CMP) to improve the cutting performance and the tool life. The study showed that in turning GH4169 nickel-based superalloy, this method made it possible to reduce the components of the cutting forces Fx, Fy and Fz by $18.26 \%, 11.37 \%$ and $13.81 \%$, respectively, and the service life compared to the insert without processing by $35.92 \%$.

At the moment, the main vector of development of carbide instruments is aimed at using complex-structured multifunctional wear-resistant coatings [30-32].

A.S. Vereschaka et al. [30] note that the architecture of multilayer wear-resistant coatings should be designed based on the properties of the material being processed. First, an intermediate high-adhesion layer must be applied, and then functional layers, which make it possible to resist abrasive and diffusion wear during the turning process.

\subsection{Cubic boron nitride for machining nickel-based alloys}

The use of cubic boron nitride (CBN) as a cutting tool in the processing of heat-resistant nickel alloys is poorly understood. Basically, CBN used in the treatment of increased material hardness (45-60 HRC), such as hardened steel [33] or ductile iron $[34,35]$.

Costes J.P. et al. [16] proposed the use of Inconel 718 for processing as a cutting tool cubic boron nitride (CBN), instead of the carbide. It was noted that the main causes of tool wear at processing CBN nickel alloys is the adhesion and diffusion, due to their chemical affinity, as well as conventional abrasion. The formation of wear along the front surface was observed, as well as uneven wear along the front surface in the form of a dimple, caused by thermal effects from the edge to the center.

R.M. Arunachalam et al. [36] note that in the process of turning nickel-based alloys diffusion of $\mathrm{Nb}, \mathrm{Cr}$, Fe and $\mathrm{Ni}$ from the workpiece into the tool occurs. Mutual diffusion was observed not in the entire volume of the material, but in certain areas, which allowed them to conclude that certain conditions were created during the cutting process, in which the chemical reaction between the tool and the processed materials was minimal.

Harris T.K. et al. [37] in their work tried to find a relationship between the CBN content, the TiC/TiN bonding phases, the grain size $(1-15 \mu \mathrm{m})$ and the physical and mechanical properties of the tool (hardness / temperature). As an evaluation method using Vickers indentation method by heating under various conditions.

Kaya E. et al. [38] conducted a study of the development of wear of polycrystalline diamond (PCD) and cubic boron nitride $(\mathrm{CBN})$ tools during high-speed (cutting speed $\mathrm{Vc}_{\mathrm{c}}=70$ $250 \mathrm{~m} / \mathrm{min}$ ) turning of NiTi alloys. It was found that both tool materials are sensitive to increased cutting speed. At cutting 
speeds up to $\mathrm{Vc}_{\mathrm{c}}=130 \mathrm{~m} / \mathrm{min}$, the dominant wear is adhesion wear and abrasion along the insert main flank surface caused by mechanical stress. By increasing, the cutting speed was observed thermal effects mainly grains chipping from the front surface. Thus, the observed diffusion, chemical and oxidative types of wear, leading to premature failure of the CBN. This study allows us to conclude that there is a limited increase in cutting speed due to its physical and mechanical characteristics.

2.3 Ceramic instruments for machining nickel-based superalloys

Ceramic tool materials in the processing of difficult-tomachine steels and alloys are slowly replacing hard alloys due to their physical and chemical properties [3].

Tool ceramics are used for a wide range of operations and materials, including high-speed finishing of high-temperature alloys. The specific properties of nickel-based heat-resistant alloys when properly used can provide high productivity.

The variety of instrument grades of ceramics and compositions appearing on the market every year makes it possible to assert the promise and interest in the material. Currently, ceramic cutting tools (ceramic inserts) are mainly represented by NTK Cutting tools (USA), NikkoTools (Italy), Sandvik Coromant (Sweden), ISCAR (Israel), Tungaloy Corporation (Japan), CeramTec (Germany) and others. Silicon nitride- and alumina-based ceramics holds a special place in processing of Ni-based superalloys.

Jun Zhao [39] identified 4 groups of instrumental materials in his work: $\mathrm{Al}_{2} \mathrm{O}_{3}$-based ceramics, $\mathrm{Si}_{3} \mathrm{~N}_{4}$-based ceramics, $\mathrm{SiAlON-based} \mathrm{ceramics} \mathrm{and} \mathrm{ceramic} \mathrm{matrix} \mathrm{composites.} \mathrm{He}$ notes the growing need ceramic instruments and highlights the stages of development from 1938 to the present day. One of the most promising ceramic materials for efficient turning Nickel-Based HRSA is $\mathrm{Al}_{2} \mathrm{O}_{3}$ with the addition of $\mathrm{TiC}$ and other hard particles such as $\mathrm{TiN},(\mathrm{W}, \mathrm{Ti}) \mathrm{C}, \mathrm{Ti}(\mathrm{C}, \mathrm{N}), \mathrm{TiB}_{2}$ and SiCw. Table 2 presents various categories, compositions and properties of $\mathrm{Al}_{2} \mathrm{O}_{3}$-based ceramic instruments for turning hardened steels and heat-resistant alloys. 
Table 2. Various categories, compositions and properties of $\mathrm{Al}_{2} \mathrm{O}_{3}$-based ceramic instruments for turning hardened steels and heat-resistant alloys.

\begin{tabular}{|c|c|c|c|c|c|c|c|}
\hline Composite & $\begin{array}{c}\text { Producer/Con } \\
\text { try }\end{array}$ & Grade & $\begin{array}{c}\text { Densit } \\
y \\
\left(\mathrm{~g} \cdot \mathrm{cm}^{-}\right. \\
\left.{ }^{3}\right)\end{array}$ & $\begin{array}{c}\text { Hardne } \\
\text { ss } \\
\text { (HRA) }\end{array}$ & $\begin{array}{c}\text { Flexur } \\
\text { al } \\
\text { strengt } \\
\text { h } \\
\text { (MPa) }\end{array}$ & $\begin{array}{c}\text { Fracture } \\
\text { toughne } \\
\text { ss } \\
\left(\mathrm{MPa} \cdot \mathrm{m}^{1}\right. \\
/ 2)\end{array}$ & $\begin{array}{c}\text { Applicatio } \\
\text { ns }\end{array}$ \\
\hline \multirow{8}{*}{$\begin{array}{c}\mathrm{Al}_{2} \mathrm{O}_{3} /(\mathrm{W}, \mathrm{Ti}) \\
\mathrm{C}\end{array}$} & Shandong & AT & 4.6 & $2040 \mathrm{HV}$ & 820 & 7.4 & \\
\hline & $\begin{array}{l}\text { University } \\
\text { (China) }\end{array}$ & & & & & & \\
\hline & Shandong & SG-4 & 6.65 & $94.7-$ & 850 & 4.94 & Machining \\
\hline & $\begin{array}{l}\text { University } \\
\text { (China) }\end{array}$ & & & 95.3 & & & $\begin{array}{c}\text { hardened } \\
\text { steels }\end{array}$ \\
\hline & Shandong & FG- & & $94.7-$ & 830 & & \\
\hline & $\begin{array}{l}\text { University } \\
\text { (China) }\end{array}$ & $\begin{array}{l}\text { 2(grade } \\
\text { d) }\end{array}$ & & 95.5 & & & \\
\hline & Shandong & AWT10 & 6.65 & $2350 \mathrm{HV}$ & 930 & 7.55 & \\
\hline & $\begin{array}{c}\text { University } \\
\text { (China) }\end{array}$ & & & & & & \\
\hline \multirow{2}{*}{$\begin{array}{c}\mathrm{Al}_{2} \mathrm{O}_{3} / \mathrm{WC} / \mathrm{Ti} \\
\mathrm{Cn}_{\mathrm{n}}\end{array}$} & Shandong & LWT-1 & 6.5 & $2340 \mathrm{HV}$ & 840 & 7.87 & \\
\hline & $\begin{array}{c}\text { University } \\
\text { (China) }\end{array}$ & & & & & & \\
\hline \multirow{5}{*}{$\mathrm{Al}_{2} \mathrm{O}_{3} / \mathrm{SiC}_{\mathrm{w}}$} & Shandong & JX-1 & 3.63 & $94-95$ & 800 & 8.5 & \multirow{5}{*}{$\begin{array}{c}\text { Machining } \\
\text { heat- } \\
\text { resistant } \\
\text { alloys }\end{array}$} \\
\hline & $\begin{array}{c}\text { University } \\
\text { (China) }\end{array}$ & & & & & & \\
\hline & Sandvik & CC670 & 3.74 & $2000 \mathrm{HV}$ & 900 & 8.0 & \\
\hline & $\begin{array}{l}\text { Coromant } \\
\text { (Sweden) }\end{array}$ & & & & & & \\
\hline & $\begin{array}{c}\text { Kennametal } \\
\text { (USA) }\end{array}$ & KY4300 & 3.74 & $2000 \mathrm{HV}$ & 700 & 7.7 & \\
\hline $\mathrm{Al}_{2} \mathrm{O}_{3} / \mathrm{TiB}_{2} / \mathrm{Si}$ & Shandong & LP-2 & 3.94 & $94-95$ & 700- & 7.8 & \\
\hline $\mathrm{C}_{\mathrm{w}}$ & $\begin{array}{c}\text { University } \\
\text { (China) }\end{array}$ & & & & 800 & & \\
\hline
\end{tabular}

Li Xikun et al. in their review highlighted a line of commercial and experimental $\mathrm{Si}_{3} \mathrm{~N}_{4}$-based ceramic instruments for processing difficult-to-machine alloys due to their high thermal resistance, high thermal conductivity, low coefficient of thermal expansion and fracture toughness. Table 3 presents various categories, compositions and properties of $\mathrm{Si}_{3} \mathrm{~N}_{4}$-based ceramic instruments $[18,39]$. 
Table 3. Various categories, compositions and properties of $\mathrm{Si}_{3} \mathrm{~N}_{4}$-based ceramic instruments.

\begin{tabular}{|c|c|c|c|c|c|c|}
\hline Brand & $\begin{array}{l}\text { Compositio } \\
\mathbf{n}\end{array}$ & $\begin{array}{l}\text { Hardnes } \\
\text { s (HRA) }\end{array}$ & $\begin{array}{l}\text { Bendin } \\
\mathrm{g} \\
\text { strength } \\
\text { (GPa) }\end{array}$ & $\begin{array}{l}\text { Densit } \\
\text { y }\left(\mathrm{g} \cdot \mathrm{cm}^{-}\right. \\
\text {3) }\end{array}$ & $\begin{array}{l}\text { Fracture } \\
\text { toughnes } \\
\mathrm{s} \\
\left(\mathrm{MPa} \cdot \mathrm{m}^{1 / 2}\right. \\
\text { ) }\end{array}$ & $\begin{array}{l}\text { Company/Countr } \\
\text { y }\end{array}$ \\
\hline HDM1 & $\mathrm{Si}_{3} \mathrm{~N}_{4}$ matrix & 92.5 & 0.93 & & & China \\
\hline HDM2 & $\begin{array}{l}\mathrm{Si}_{3} \mathrm{~N}_{4} \text { matrix, } \\
\mathrm{SiC}_{w} \text { fiber }\end{array}$ & 93 & 0.98 & & & \\
\hline HDM3 & $\mathrm{Si}_{3} \mathrm{~N}_{4}$ matrix & 92.5 & 0.83 & & & \\
\hline N55555 & $\mathrm{Si}_{3} \mathrm{~N}_{4}$ matrix & $(\geq 96.5)$ & & & & \\
\hline CC680 & $\begin{array}{l}\mathrm{Si}_{3} \mathrm{~N}_{4-}-\mathrm{Al}_{2} \mathrm{O}_{3}- \\
\mathrm{Y}_{2} \mathrm{O}_{3}\end{array}$ & $93.5 \sim 94.5$ & $1.0 \sim 1.3$ & & & $\begin{array}{l}\text { Sandvik } \\
\text { Coromant } \\
\text { (Sweden) }\end{array}$ \\
\hline KY3000 & $\begin{array}{l}77 \% \mathrm{Si}_{3} \mathrm{~N}_{4-} \\
13 \% \mathrm{Al}_{2} \mathrm{O}_{3-} \\
10 \% \mathrm{Y}_{2} \mathrm{O}_{3}\end{array}$ & $\begin{array}{l}1800 \\
(\mathrm{HV})\end{array}$ & $1.0 \sim 1.3$ & & & $\begin{array}{c}\text { Kennametal } \\
\text { (USA) }\end{array}$ \\
\hline Kyon2000 & $\begin{array}{l}\text { No pressure } \\
\text { sintered } \\
\text { Sialon }\end{array}$ & $\begin{array}{l}1800 \\
(\mathrm{HV})\end{array}$ & 765 & $3.2 \sim 3.4$ & 6.5 & USA \\
\hline $\begin{array}{l}\text { Quantum500 } \\
0\end{array}$ & $\begin{array}{l}\text { Hot pressing } \\
\mathrm{Si}_{3} \mathrm{~N}_{4}-\mathrm{TiC}\end{array}$ & 93.5 & 750 & 3.4 & 4.3 & \\
\hline Lsay & $\begin{array}{l}\text { Hot pressing } \\
\mathrm{Si}_{3} \mathrm{~N}_{4}+\mathrm{Y}_{2} \mathrm{O}_{3}\end{array}$ & $\begin{array}{l}2150 \\
(\mathrm{HV})\end{array}$ & 714 & 3.2 & & \\
\hline SX7 & & 93.0 & 1100 & & 7.0 & Japan \\
\hline FX920 & & 92.8 & 960 & 3.27 & 9.4 & \\
\hline FX910 & & 94.7 & 760 & 3.32 & 6.7 & \\
\hline Naycon & & 92.8 & 1000 & 3.23 & & \\
\hline NCT & $\begin{array}{l}\text { Hot pressing } \\
\mathrm{Si}_{3} \mathrm{~N}_{4}\end{array}$ & 92.6 & 816 & 3.3 & 6.7 & Germany \\
\hline KY1540 & $\alpha / \beta-S i A l O N$ & 18.24 & & 3.35 & 7.45 & $\begin{array}{c}\text { Kennametal } \\
\text { (USA) }\end{array}$ \\
\hline
\end{tabular}

\section{Features of SiAlONs and their application in the pro- cessing of nickel-based HRSA}

As it is known, nickel alloys are very difficult to cut materials due to high chemical affinity and poor thermal conductivity that they have in conjunction with the presence of hardabrasive carbides in their microstructure and the work-hardening that occurs during machining. For this reason, in order to carry out efficient machining of this type of alloys, it is 
necessary to select the appropriate cutting tool and define the most optimal machining parameters for the tool-part pairs.

Unfortunately, high-speed machining of nickel alloys using cemented carbide, results in a weakness of the cutting tools characteristics mainly due to the occurring ultra-high local temperature that leads to the reduction in tool life.

In mass production, the use of high-speed machining is essential. Unfortunately, this type of machining for nickel alloys using cemented carbide is not feasible due to the loss of the cutting tools characteristics mainly related to the ultrahigh local temperature that occurs in the tool-part contact zone, which leads to a reduction in the useful life of the tool. One of the ways to solve the negative effects that happened by machining of nickel alloys at high cutting speeds is the use of ceramic cutting tools, which can keep for a long time even at high temperatures, their chemical stability and high wear resistance and hardness.

SiAlON was developed in the 1970 s and prepared by hot pressing with $\mathrm{Si}_{3} \mathrm{~N}_{4}$ as hard phase, $\mathrm{Al}_{2} \mathrm{O}_{3}$ as abrasion resistance phase and a small amount of $\mathrm{Y}_{2} \mathrm{O}_{3}$ as sintering aids. SiAlON are formed when silicon nitride $\left(\mathrm{Si}_{3} \mathrm{~N}_{4}\right)$, aluminium oxide $\left(\mathrm{Al}_{2} \mathrm{O}_{3}\right)$ and aluminium nitride $(\mathrm{AlN})$ are reacted together.

SiAlON cutting tools have some special features such as good fracture toughness, hardness (even at high temperatures) and resistance to sudden temperature changes, which make it a suitable material for machining of various difficult to cut materials including nickel alloys. SixAlxOxNx is characterized by high chemical inertness and low coefficient of thermal expansion, therefore, when cutting, there is a more uniform and predictable wear, without grooves and chipping.

There are several kinds of SiAlON ceramics as an example $\alpha$-SiAlON, $\beta$-SiAlON and their combination $(\alpha+\beta)$. The most commonly used compositions at present are $\beta$-SiAlON and $(\alpha+\beta)$ SiAlONs, which contain a substantial excess of sintering aids. However, the field is still changing with compositions developing to suit specific applications.

\section{1. $\alpha-\operatorname{SiAlON}$}

$\alpha$-SiAlONs are isostructural with $\alpha-\mathrm{Si}_{3} \mathrm{~N}_{4}$ where m $(\mathrm{Si}-\mathrm{N})$ bonds are replaced by $m(\mathrm{Al}-\mathrm{N})$ bonds and $\mathrm{n}(\mathrm{Si}-\mathrm{N})$ bonds by $\mathrm{n}(\mathrm{Al}-\mathrm{O})$ bonds. Crystal structure of $\alpha$-SiAlONs requires an extra cation for stability. Formula of the $\alpha$-Sialons is $M_{x}^{v+} \mathrm{Si}_{12-\mathrm{m} \text { - }}$ n $\mathrm{Al}_{\mathrm{m}+\mathrm{n}} \mathrm{O}_{\mathrm{n}} \mathrm{N}_{16-\mathrm{n}}$, where $\mathrm{M}$ can be $\mathrm{Li}, \mathrm{Mg}, \mathrm{Ca}, \mathrm{Y}$ and/or a rare earth element, depending on its ionic radius [40] or with using quenching. Some larger cations can enter the structure only in combination with other cations. The $x$ value $(x=m / v)$ is mostly between 0.3 and 1.0. The $\alpha$-SiAlON phase (especially with high $\mathrm{x}$ ) is stable only at high temperatures and transform to $\beta$ Sialon and other crystalline or glassy phases by heat treatment.

The $\alpha$-SiAlONs are very attractive because of their hardness and the ability to improve high-temperature properties by reducing the amount of residual glassy phase, but these materials are brittle, and improved fracture toughness is desirable without significant reduction of the hardness. Ekström 
in his work [41] described some results about $\alpha$-SiAlON, which can be summarized as follows:

1. Dense $\alpha$-SiAlONs may act as the matrix in composite materials with $\mathrm{SiC}$-whiskers or $\mathrm{MoSi}_{2}$-particulates. Chemical compatibility is good, but with $\mathrm{SiC}$ the toughness was not significantly improved and with $\mathrm{MoSi}_{2}$ the drop in hardness was unacceptable.

2. The rare earth elements with large ion sizes (i.e. Sm and $\mathrm{Nd}$ ) cannot be used to stabilize $\alpha$-phases in ceramics used at high temperatures, because these $\alpha$-phases decompose at $\sim 1000-1650^{\circ} \mathrm{C}$. These ceramics should be used at low temperatures.

3. Yttrium and the rare earth elements with small ion sizes (i.e. $\mathrm{Yb}$ and $\mathrm{Dy}$ ) form $\alpha$-phases that are stable at high temperatures, and these additives are very usefull for future $\alpha$-SiAlONs ceramics at all temperatures.

In order to prolong the useful life of the $\alpha$-SiAlON-based cutting tool, different works have been developed based on the addition of different phases to the ceramic structure. For example, Salomon et al. and Rosenflanz et al. [42, 43] prepared and developed new ceramic cutting tools on the base of $\alpha$-SiAlON with other complementary phases, which provide a significant improvement in the mechanical properties and chemical resistance. Table 4 shows the mechanical properties and tool lives obtained in this work.

Table 4. Mechanical properties and tool lives obtained in [42]

\begin{tabular}{|c|c|c|c|c|c|}
\hline Sample & Composition & Minor phases & $\begin{array}{l}\text { HV1 } \\
\text { (GPa) }\end{array}$ & $\begin{array}{c}\mathrm{K}_{1 \mathrm{C}} \\
\left(\mathrm{MPa} \cdot \mathrm{m}^{1 / 2}\right)\end{array}$ & $\begin{array}{l}\text { Tool } \\
\text { life } \\
\text { (min) }\end{array}$ \\
\hline A039 - HIP1 & $\alpha$-Sialon & - & $20.2 \pm 0.5$ & $6.8 \pm 0.3$ & 17.5 \\
\hline A039 - HIP1 & $\alpha$-Sialon & $\begin{array}{c}\mathrm{Y}_{2} \mathrm{O}_{3}, \mathrm{La}_{5} \mathrm{Si}_{3} \mathrm{NO}_{12} \\
\mathrm{Y}_{10} \mathrm{Al}_{2} \mathrm{Si}_{3} \mathrm{O}_{18} \mathrm{~N}_{4}\end{array}$ & $14.2 \pm 0.5$ & $6.2 \pm 0.2$ & 20.4 \\
\hline A057 - HIP1 & $\alpha$-Sialon & $\begin{array}{c}\mathrm{SiAl}_{6} \mathrm{O}_{2} \mathrm{~N}_{6}, \mathrm{Y}_{2} \mathrm{O}_{3}, \\
\mathrm{La}_{2} \mathrm{O}_{3}\end{array}$ & $17.0 \pm 0.5$ & $6.7 \pm 0.2$ & 31.0 \\
\hline A057 - HIP3 & $\begin{array}{l}\beta \text {-Sialon, } \alpha- \\
\text { Sialon }\end{array}$ & $\mathrm{SiAl}_{6} \mathrm{O}_{2} \mathrm{~N}_{6}$ & $15.1 \pm 0.5$ & $6.7 \pm 0.2$ & 20.0 \\
\hline A057 - HIP4 & $\alpha$-Sialon & $\mathrm{SiAl}_{6} \mathrm{O}_{2} \mathrm{~N}_{6}$ & $17.7 \pm 0.7$ & $6.2 \pm 0.3$ & 27.5 \\
\hline B069 - HIP3 & $\beta$-Sialon & - & $14.4 \pm 0.2$ & $7.0 \pm 0.3$ & 23.3 \\
\hline A039 - HIP5 & $\beta$-Sialon & $\mathrm{SiAl}_{6} \mathrm{O}_{2} \mathrm{~N}_{6}$ & $19.7 \pm 0.5$ & $6.9 \pm 0.1$ & - \\
\hline
\end{tabular}

The best results were obtained for the samples A057 HIP1, A057 - HIP4 and B069 -HIP3 because the tool life is longer than usually obtained for the $\beta-\mathrm{Si}_{3} \mathrm{~N}_{4}$ cutting tools (with keeping other important requirements as roughness of workpiece etc.). The sample A039 - HIP5 was used to compare the phase composition of two differently cooled samples. Scientists found that the presence of defects and polytype $21 \mathrm{R}$ 
$\left(\mathrm{SiAl}_{6} \mathrm{O}_{2} \mathrm{~N}_{6}\right)$ has a negative influence on cutting performance. However, the presence of homogeneity of the microstructure and pure $\alpha$-SIAION and $\beta$-SIAION with good ratio between elongated and submicron grains provide positive influence on cutting performance. Moreover, authors determined that pure $\alpha$ - or $\beta$-SIAIONs have better cutting performance compared with $\beta$-Si3N4; that inhomogeneities and polytype $21 \mathrm{R}$ have higher effect on cutting performance than on macro-mechanical properties (HV1, K1c10); and that it is possible to change the phase composition just by modification of the cooling rate (A039 - HIP 1 vs. A039 HIP 5).

\section{2. $\beta$-SiAlON}

$\beta$-Sialon are formed by substituting $\mathrm{Si}$ in the $\beta-\mathrm{Si}_{3} \mathrm{~N}_{4}$ structure by $\mathrm{Al}$ provided valence compensation by replacement equivalent concentration of $\mathrm{N}$ by $\mathrm{O}$. A general formula of $\beta$ SIAlONs is Si6-z $\mathrm{Al}_{z} \mathrm{O}_{z} \mathrm{~N}_{8-z}$, with $0<\mathrm{z}<4$.2, where $\mathrm{z}$ ( $\mathrm{Si}-\mathrm{N}$ ) bonds are replaced by $\mathrm{z}(\mathrm{Al}-\mathrm{O})$ bonds [40]. $\beta$-SiAlONs are isostructural with $\beta$-Si3 $\mathrm{N}_{4}$. $\beta$-SiAlON ceramics are promising materials for applications involving high temperatures, highly corrosive environments, and high mechanical stress because they exhibit high strength retention and high thermal shock resistance at elevated temperatures as well as good erosion resistance and low creep [44-48]. Compared with $\mathrm{Si}_{3} \mathrm{~N}_{4}, \beta-\mathrm{SiAlON}$ ceramics are not only easily sintered and fabricated but also can be easily combined with other materials to strengthen or improve the properties of ceramics [49-50].

$\beta$-SIAION ceramics dominated the early interest because they could be pressurelessly sintered into complex shapes, and the resulting materials had a good combination of properties; for example, some pressurelessly sintered $\beta$-SIAlON ceramics have strengths of up to $1000 \mathrm{MPa}$ and fracture toughnesses of up to $8 \mathrm{MPa} \cdot \mathrm{m}^{1 / 2}[51]$.

Due to its high mechanical characteristics, recently the $\beta$ SIAION has been used even in additive technologies to obtain parts with complex spatial shapes, for instance, Tian et al. [52], used $\mathrm{Si}_{3} \mathrm{~N}_{4}, \mathrm{Al}_{2} \mathrm{O}_{3}$ and $\mathrm{AlN}$ particles as raw materials for the design of $\beta$-SiAlON ceramics with different main crystal phases. In this work, the green body of the $\beta$-SiAlON-matrix ceramic samples were obtained by using stereolithography (SLA) additive manufacturing. After degreasing, dense $\beta$-SiAlON ceramics with different SiAlON phases were fabricated through gas pressure sintering at $1800{ }^{\circ} \mathrm{C}$ for 1 hour at $3 \mathrm{GPa}$. Moreover, the authors studied the effects of the different $\mathrm{Al}_{2} \mathrm{O}_{3}$ contents on the shrinkage, phase composition, relative density, microstructure, mechanical property and hardness. The obtained results indicate that the main phase of the ceramics was $\beta$-SiAlON and the specific chemical compositions of it were $\mathrm{Si}_{5} \mathrm{AlON}_{7}, \mathrm{Si}_{3.1} \mathrm{Al}_{2.9} \mathrm{O}_{2.9} \mathrm{~N}_{5.1}$ and $\mathrm{Si}_{2} \mathrm{Al}_{4} \mathrm{O}_{4} \mathrm{~N}_{4}$, with mainly intergranular phases of $\mathrm{Y}_{3} \mathrm{Al}_{5} \mathrm{O}_{12}, \mathrm{YAlO}_{3}$ and $\mathrm{Al}_{2} \mathrm{O}_{3}$. The sintered $\beta$-Sis $\mathrm{AlON}_{7}$ ceramics had a relative density of $90.03 \%$, with Vickers hardness (HV5), bending strength and fracture toughness of $16.7 \mathrm{GPa}, 465 \mathrm{MPa}$ and $4.84 \mathrm{MPa} \cdot \mathrm{m}^{1 / 2}$, respectively. Meanwhile, the shrinkage of the materials was $28.7 \%$. 
Dense $\beta$-sialon ceramics with low $\mathrm{z}$ values $(\mathrm{z} \sim 1)$ have microstructures consisting of elongated crystals and grain boundary glass, and of all the various sialon materials, show the highest observed fracture toughness values at room temperature; however, their hardness is relatively low (14-15 GPa) partly because of the residual grain boundary glass $(\sim 10$ GPa) [53]. Because of this, in cutting tools $\beta$-SIAION is used as a reinforce phase that provides strength and toughness.

\section{3. $(\alpha+\beta)$ SiAlON}

The $\alpha-\beta$ SiAlON combinations with a minimum of glassy phase, are currently the most promising materials for further use, both at low and high temperatures [41].

The hardness of $\beta$-sialon ceramics is relatively low (14-15 $\mathrm{GPa})$, in contrast, $\alpha$-sialon ceramics generally have equiaxed grains and show an excellent hardness ( $22 \mathrm{GPa})$, much higher than that of any other sialon ceramics. The properties of mixed $\alpha / \beta$-sialon ceramics can be optimised by adjusting the proportion of the two phases, and this can be done by changing the starting composition [54]. A high content of $\beta$ - sialon yields high strength and toughness, whereas a high proportion of the $\alpha$-sialon phase gives excellent hardness. Mixed $\alpha / \beta$-sialon ceramics can be produced with very little intergranular glass and so their wear resistance, strength and especially creep resistance at high temperatures are greatly improved [53]. For instance, with a $\alpha-\beta$ ratio around 50:50 it is possible to prepare very hard (HV10 around $22 \mathrm{GPa}$ ) and tough $\alpha-\beta$ SiAlONs with an indentation fracture toughness of $5.5 \mathrm{MPa} \cdot \mathrm{m}^{1 / 2}$ [41].

Thanks to the excellent properties that $(\alpha+\beta)$-SIAIONs have, they are used in the production of cutting tools. For example, Mandal et al. [55] designed $(\alpha+\beta)$-SIAlON ceramics, which were produced in aqueous medium using multiple oxides as densifying additives. The sintered samples machined to cutting tool geometries were tested in turning and milling operations of cast iron and superalloy and the results were compared with some commercially available ceramic inserts. Hardnesses of the sintered $(\alpha+\beta)$-SIAlONs are about $19 \mathrm{GPa}$, whereas hardness of most commercial $\mathrm{Si}_{3} \mathrm{~N}_{4}$ is $15-16 \mathrm{GPa}$. The authors concluded that by a careful design of grain boundary chemistry (starting composition and sintering additives), $(\alpha+\beta)$-SIAlONs ceramics can be produced and successfully used in machining operations.

In other work, Bitterlich et al. [56] made a first attempt to use particles such as $\mathrm{SiC}, \mathrm{WC}, \mathrm{MoSi}_{2}$ and $\mathrm{Ti}(\mathrm{C}, \mathrm{N})$ for $(\alpha+\beta)$ SiAlON-composites for cutting tool applications. Although these composites did not produce satisfying results, they showed potential for further optimization.

The $(\alpha+\beta)$-SiAlON-composites with different reinforcing particles (SiC, $\mathrm{Ti}(\mathrm{C} 30 \mathrm{~N} 70), \mathrm{MoSi}$, WC) were prepared by gas pressure sintering. Under the sintering conditions a strong interaction of $\mathrm{MoSi}_{2}$ and WC with the matrix was observed, resulting in a change of the composition of the reinforcing phase and also of the $(\alpha+\beta)-S i A l O N$ ratio. This strongly influenced the properties of the composites. The best wear behaviour 
exhibited the material with 10 vol\% SiC. The material reinforced with $\mathrm{MoSi}_{2}$ showed a reasonable wear behaviour - despite its low fracture toughness and low hardness - indicating some special effects, which should be investigated in more detail.

\subsection{SiAlON application in machining nickel-based alloys}

Due to the physical and mechanical properties of SIAlONs used as cutting tools, their use in the processing of nickel alloys is very widespread. Much research has been done to determine the effectiveness of sialons application compared to other ceramics. For instance, Krebs et al. [57] investigated the use of whiskers-reinforced ceramic tools and SiAlON in turning of alloy 625 clad on AISI 4130 steel by an automatic tungsten inert gas (TIG) cladding system. The results indicate the feasibility of the industrial application of the SiAlON inserts in rough turning of the alloy $625 \mathrm{clad}$, as well as the impossibility of using whiskers-reinforced ceramic tools $\left(\mathrm{Al}_{2} \mathrm{O}_{3}+\mathrm{SiCw}\right)$ in the same conditions. It was determined that considerably higher material removal rates can be achieved with SiAlON, instead of using conservative cutting parameters with coated cemented carbide tools. Tool wear pattern of the SiAlON inserts were similar for the different cutting conditions. Wear occurred on the flank face in formation of a relative uniform flank wear and high V-shaped notch wear. The highest flank and notch wear were observed for the lowest cutting speed $(140 \mathrm{~m} / \mathrm{min})$, which induced the formation of burrs in the workpiece at the depth of cut. Adhesion occurred more intensively at this condition. The least flank and notch wear were achieved by using cutting speed of $160 \mathrm{~m} / \mathrm{min}$ and feedrate of $0.25 \mathrm{~mm} / \mathrm{rev}$. Prolonged turning with worn tools resulted in microstructural alterations of the workpiece material and surface damages like cavities that may be associated with the carbide particles inside the machined surface.

Lima Fabio F. et al. [58] conducted a study on turning a nickel-based superalloy Inconel 751 using argon and oxygen atmospheres. Three groups of materials were used as cutting tools: $\mathrm{SiAlON}\left(\mathrm{Si}_{3} \mathrm{~N}_{4}+\mathrm{Al}_{2} \mathrm{O}_{3}\right)$, Whisker $\left(\mathrm{Al}_{2} \mathrm{O}_{3}+\mathrm{SiCw}\right)$ and Mixed $\left(\mathrm{Al}_{2} \mathrm{O}_{3}+\mathrm{TiC}\right)$. Experiments have shown that cutting speed, tool geometry and cutting fluid affect the type of wear and tool life. However, the best results have been achieved with SiAlON tools.

Zheng et al. [59] investigated the wear mechanisms of a Sialon ceramic tool in ultra-high-speed turning Inconel 718. The main wear mechanisms identified in the experimental part were adhesive and mechanical wear. SEM and EDS, during critical wear on the inserts edge, deposits in the form of separate elements $\mathrm{Ni}, \mathrm{Fe}$ and $\mathrm{Cr}$ were found, contributing to a more active development of wear. The author also noted a serrated morphology shaving, indicating that thermal deformation during the cutting process.

Li et al. [60] in their work determined the optimal cutting speed when processing Inconel 718, at which there are no 
diffusion phenomena that contribute to the formation of cuts on the back surface and craters on the front surface.

Nalbant et al. [61] studied the wear mechanisms of SiAlON tools when machining a nickel alloy with plates having different geometric shapes (RNGN 120700 and SNGN 120712). Practice has shown that the predominant failures of square plates are crater wear along the front surface and mechanical wear along the rear surface, while for round plates the formation of notches and mechanical wear on the rear surface. The authors explain this by the fact that round inserts allow the use of different plunge angles, depending on the processing modes. This allows you to control piercing and notching.

Zheng et al. [62] proposed a new composition of SiAlON tools, strengthening it by introducing graded nano- $\alpha-\mathrm{Si}_{3} \mathrm{~N}_{4}$ into its composition. The experimental material made it possible to reduce the coefficient of friction and reduce the adhesive reactions. Mechanical tests showed that the introduction of $\alpha$ $\mathrm{Si}_{3} \mathrm{~N}_{4}$ made it possible to reduce microcracks on the working parts of the inserts, which made it possible to increase the cutting speed up to $300 \mathrm{~m} / \mathrm{min}$.

Shalaby et al. [63] used SiAlON ceramic tools in processing of aerospace superalloy Inconel 100 (IN100). The effect of cutting speed on chip formation in dry finish turning was investigated. It is noted in the work that a change in cutting speeds in a certain range leads to the formation of various lubricating and protective tribo-films that contribute to the elimination of the development of microcracks and defects.

\section{Conclusions}

The review showed that effective Nickel-Based HRSA treatment is a pressing issue. The most promising direction of development is the use of progressive methods of introducing alloying elements into the $\mathrm{SiAlON}$ and $\mathrm{Si}_{3} \mathrm{~N}_{4}$ ceramic matrix. Due to their natural properties, traditional materials such as carbide, CBN, and PCD have functional limitations and low processing potential for Nickel-based alloys.

In the third section, SiAlON cutting tools were considered as a suitable material for machining a variety of difficult-to-cut materials, including nickel alloys, due to their special characteristics such as good fracture toughness, hardness (even at high temperatures) and resistance to sudden changes in temperature. In addition, this section provides a description of the various types of SiAlON ceramics such as $\alpha$-SiAlON, $\beta$-Si$\mathrm{AlON}$ and their combinations $(\alpha+\beta)$. Examples of the use of sialons in the processing of nickel-based superalloys are given.

Author Contributions: Conceptualization, A.S. and A.S.; data curation, N.W.S.P.; formal analysis, A.S. and A.S.; funding acquisition, A.S.; investigation, N.W.S.P.; methodology, A.S. and A.S.; project administration, A.S. and A.S.; resources, A.S., A.S., N.W.S.P.; supervision, A.S. and A.S.; visualization, A.S. and N.W.S.P.; writing-original draft, A.S. 
All authors read and approved the final version of the manuscript

Funding: We would like to thank the Ministry of Science and Higher education of the Russian Federation for supporting this work under the grant number 20-79-00222.

Conflicts of Interest: The authors declare no conflict of interest.

\section{References}

[1] Sommitsch, C.; Radis, R.; Krumphals, A.; Stockinger, M; Grill, D. Microstructure control in processing nickel, titanium and other special alloys. Microstructure evolution in metal forming processes. In Woodhead Publishing Series in Metals and Surface Engineering;Woodhead: Cambridge, England. 2012: pp. 337-383.

[2] Pollock, T.M. Nickel-Based Superalloys for advanced turbine engines. Journal of Propulsion and Power. 2006, vol. 22 (2): pp. 361-374.

[3] Richards, N; Aspinwall, D. Use of ceramic tools for machining nickel-based alloys. Int. J. Mach. Tool Manf. 1989, vol. 10, pp. 575-588.

[4] Liu, L.; Zhang, J.; Ai, C. Nickel-based superalloys. Reference Module in Materials Science and Materials Engineering. 2020.

[5] Thellaputta, G.R.; Chandra Bose, P.S.; Rao, C.S.P. Machinability of nickel-based superalloys: A Review. Mat. Today: Proceed. 2017, vol. 4 (2), pp. 3712-3721.

[6] Ezugwu, E.O; Bonney, J.; Yamane, Y. An overview of the machinability of aeroengine alloys. J. Mat. Process. Tech. 2003, vol. 134, pp. 233-253.

[7] Pervaiz, S.; Rashid, A.; Deiab, I.; Nicolescu, M. Influence of tool materials on machinability of titanium- and nickel-based alloys: A review. Mat. Manufac. Proc. 2014, vol. 29, pp. 219-252. [8] Thakur, A.; Gangopadhyay, S. State-of-the-art in surface integrity in machining of nickel-based super alloys. Int. J. Mach. Tools Manufacture. 2016, vol. 100, pp. 25-54.

[9] Noor, M.M.; Kadirgama, K.; Habeeb, H.N.; Rahman, M.M.; Mohammad, B. Performance of carbide cutting tools when machining of nickel-based alloy. Int. J. Mat. Form. 2010, vol. 3, pp. 475-478.

[10] Polvorosa, R.; Suárez, A.; López de Lacalle, L.N.; Cerrillo, I.; Wretland, A.; Veiga, F. Tool wear on nickel alloys with different coolant pressures: Comparison of Alloy 718 and Waspaloy. J. Manufac. Proc. 2017, vol. 26, pp. 44-56. 
[11] Veldhuis, S.C.; Dosbaeva, G.K.; Elfizy, F.; Fox-Rabinovich, G.S.; Wagg, T. Investigations of white layer formation during machining of powder metallurgical Ni-based ME 16 superalloy. J. Mat. Eng. Perf. 2010, vol. 19(7), pp. 1031-1036.

[12] Devillez, A.; Le Coz, G.; Dominiak, S.; Dudzinski, D. Dry machining of Inconel 718, workpiece surface integrity. J. Mat. Proc. Tech. 2011, vol. 211, pp. 1590-1598.

[13] Grigoriev, S.; Pristinskiy, Y.; Volosova, M.; Fedorov, S.; Okunkova, A.; Peretyagin, P.; Smirnov, A. Wire electrical discharge machining, mechanical and tribological performance of TiN reinforced multiscale SiAlON ceramic composites fabricated by Spark Plasma Sintering. Appl. Sci. 2021, vol. 11:657.

[14] L. Settineri, R. Levi Surface Properties and Performance of Multilayer Coated Tools in Turning lnconel. CIRP Annals Manufacturing Technology. 2005, vol. 54(1), pp. 515-551.

[15] Khidhir, B.A.; Mohamed, B. Machining of nickel based alloys using different cemented carbide tools. Journal of Engineering Science and Technology. 2010, vol. 5 (3), pp. 264-271. [16] Vereschaka, A.; Tabakov, V.; Grigoriev, S.; Sitnikov, N.; Andreev, N.; Milovich, F. Investigation of wear and diffusion processes on rake faces of carbide inserts with Ti-TiN(Ti, $\mathrm{Al}, \mathrm{Si}) \mathrm{N}$ composite nanostructured coating. Wear. 2018, vol. 416-417, pp. 72-80.

[17] Costes, J.P.; Guillet, Y.; Poulachon, G.; Dessoly M. Tool-life and wear mechanisms of CBN tools in machining of Inconel 718. International Journal of Machine Tools \& Manufacture. 2007, 47, pp. 1081-1087.

[18] Xikun, L., Jing, L., Like, Q.; Tong, C; Guanming, Q; Yanbin, S. Composition, Characteristics and Development of Advanced Ceramic Cutting Tools. Journal of rare earths. 2007, vol. 25, pp. 287-294.

[19] Volosova, M. A.; Grigor'ev, S. N.; Kuzin, V. V. Effect of Titanium Nitride Coating on Stress Structural Inhomogeneity in Oxide-Carbide Ceramic. Part 4. Action of Heat Flow. Refractories and Industrial Ceramics. 2015, vol. 56(1), pp. 91-96. [20] Volosova, M. A.; Grigor'ev, S. N.; Kuzin, V. V. Effect of Tinaium Nitride Coatings on Stress Structural Inhomogeneity in Oxide-Carbide Ceramic. Part 2. Concentrated Force Action1. Refractories and Industrial Ceramics. 2015, vol. 55(5), pp. 487-491. [21] Kuzin, V. V.; Grigoriev, S. N.; Fedorov, M. Yu. Role of the thermal factor in the wear mechanism of ceramic tools. Part 2: 
Microlevel. Journal of Friction and Wear. 2015, vol. 36(1), pp. 4044.

[22] Kuzin, V. V.; Grigor'ev, S. N.; Volosova, M. A. Effect of a TiC Coating on the Stress-Strain State of a Plate of a HighDensity Nitride Ceramic Under Nonsteady Thermoelastic Conditions. Refractories and Industrial Ceramics. 2014, vol. 54(5), pp. 376-380.

[23] Kuzin, V. V.; Grigor'ev, S. N.; Volosova, M. A. Effect of a TiC Coating on the Stress-Strain State of a Plate of a HighDensity Nitride Ceramic Under Nonsteady Thermoelastic Conditions. Refractories and Industrial Ceramics. 2014, vol. 54(5), pp. 376-380.

[24] Kuzin, V.V.; Grigoriev, S. N.; Volosova, M. A. The role of the thermal factor in the wear mechanism of ceramic tools: Part 1. Macrolevel. Journal of Friction and Wear. 2014, vol. 35(6), pp. 505-510.

[25] Byrne, G.; Dornfeld, D.; Denkena, B. Advancing Cutting Technology. CIRP Annals - Manufacturing Technology. 2003, vol. 52(2), pp. 483-507.

[26] Arunachalam, R.; Mannan, M.A. Machinability of nickelbased high temperature alloys. Machining Science and Technology: An International Journal. 2000, vol. 4:1, pp. 127-168.

[27] Conaway, H.R. Machining the High Nickel Alloys, Influence of Metallurgy on Machinability. American Society for Metals. 1975, pp. 247-256.

[28] Koseki, S.; Inoue, K.; Usuki, H. Damage of Physical Vapor Deposition Coatings of Cutting Tools during Alloy 718 Turning. Precision Engineering. 2015, vol. 44, pp. 41-54.

[29] Hu, Z.; Qin, C.; Chen, X.; Tang, A.; Fang, T.; Yang, Z.; Luo, S.; Mao, M. Chemical-Mechanical Polishing of Cemented Carbide Insert Surface for Extended Tool Life in Turning of GH4169 Nickel-Based Superalloy. International Journal of Precision Engineering and Manufacturing. 2020, vol. 21(8), pp. 1421-1435.

[30] Vereschaka, A. S.; Vereschaka, A. A.; Savushkin, G. Ju.; Sivenkov, A. S. Multilayer nanostructured coatings for cutting tools. Inorganic Materials: Applied Research. 2014, vol. 5(5), pp. 522-529.

[31] Vereschaka, A.; Tabakov, V.; Grigoriev, S.; Aksenenko, A.; Sitnikov, N.; Oganyan, G.; Seleznev, A.; Shevchenko, S. Effect of adhesion and the wear-resistant layer thickness ratio on mechanical and performance properties of $Z R N$ - $(Z R, A L, S I) N$ coatings. Surface and Coatings Technology. 2019, vol. 357, pp. 218-234. 
[32] Vereschaka, A.S.; Grigoriev, S. N.; Tabakov, V.P.; Sotova, E.S.; Vereschaka, A.A.; Kulikov, M.Yu. Improving the Efficiency of the Cutting Tool Made of Ceramic when Machining Hardened Steel by Applying Nano-Dispersed Multi-Layered Coatings. Key Engineering Materials. 2013, vol. 581, pp. 68-73.

[33] Niaki, F.A.; Haines, E.; Dreussi, R.; Weyer, G. Machinability and Surface Integrity Characterization in Hard Turning of AISI 4320 Bearing Steel Using Different CBN Inserts. Procedia Manufacturing. 2020, vol. 48, pp. 598-605.

[34] Tu, L.; Tian, S.; Xu, F.; Wang, X.; Xu, C.; He, B.; Zuoa, D.; Zhang, W. Cutting performance of cubic boron nitride-coated tools in dry turning of hardened ductile iron. Journal of manufacturing processes. 2020, Vol. 56, pp. 158-168.

[35] Patel, V.D.; Gandhi, A.H. Modeling of cutting forces considering progressive flank wear in finish turning of hardened AISI D2 steel with CBN tool. The International Journal of Advanced Manufacturing Technology. 2019, vol. 104(1), pp. 114.

[36] Arunachalam, R.M.; Mannan, M.A. Performance of CBN cutting tools in facing of age hardened Inconel 718. Conference: Transactions of NAMRI/SME. 2004, vol. 32, pp. 525-532.

[37] Harris, T.K.; Brookes, E.J.; Taylor; C.J. The effect of temperature on the hardness of polycrystalline cubic boron nitride cutting tool materials. International Journal of Refractory Metals and Hard Materials. 2004, vol. 22, pp. 105-110. [38] Kaya, E.; Kaya, İ. Tool wear progression of PCD and PCBN cutting tools in high speed machining of NiTi shape memory alloy under various cutting speeds. Diamond and Related Materials. 2020, vol. 105, 107810.

[39] Zhao, J. The use of ceramic matrix composites for metal cutting applications. Advances in ceramic matrix composites. 2014, pp. 537-569.

[40] Mandal, H.; Hoffmann, M. J. Preparation of MultipleCation alpha-SiAlON Ceramics Containing Lanthanum. Journal of the American Ceramic Society. 1999, vol. 82(1), pp. 229232.

[41] Ekström, T. $\alpha$ SiAlON and $\alpha-\beta S i A l O N$ Composites; Recent Research. Engineering Ceramics '96: Higher Reliability through Processing. NATO ASI Series (3. High Technology). 1997, vol 25, pp. 147-167. 
[42] Salamon, D.; Šajgalík P.; Liška M. Mechanical Properties and Microstructure of $\alpha$-SiAlON Based Cutting Tools. Key Engineering Materials. 2005, vol. 290, pp. 250-253.

[43] Rosenflanz, A.; Chen, I.-W. Phase Relationships and Stability of $\alpha^{\prime}$-SiAlON. Journal of the American Ceramic Society. 1999, vol. 82(4), pp. 1025-1036.

[44] Cozzan, C.; Griffith, K.J.; Laurita, G.; Hu, J.G.; Grey, C.P.; Seshadri R. Structural evolution and atom clustering in $\beta$ SiAlON: $\beta$-Si6-zAlzOzN8-z. Inorg. Chem. 2017, vol. 56 (4), pp. 2153-2158.

[45] Hou, X.M.; Yue, C.S.; Zhang, M.; Chou, K.C. Thermal oxidation of SiAlON powders synthesized from coal gangue. International Journal of Minerals, Metallurgy and Materials. 2011, vol. 18 (1), pp. 77-82.

[46] Li, Y.; Liu, D.; Jin, H.; Ding, D.; Xiao, G.; Shi, Z.; Jin, Z. Effect of $Z$ values on the microstructure and mechanical properties of post-sintered reaction bonded $\beta$-SiAlON. High Temp. Mater. Process. 2017, vol. 36 (5), pp. 453-458.

[47] Zhang, M.; Chen, Z.; Huang, J.; Wang, S.; Xiong, Q.; Feng, Z.; Liu, Q.; Sun, Z.; Li X. In situ nitriding reaction formation of $\beta$-Sialon with fibers using transition metal catalysts. Ceram. Int. 2019, vol. 45 (17), pp. 21923-21930.

[48] Xiong, Q.M.; Chen, Z.; Huang, J.T.; Zhang, M.; Song, H.; Hou, X.F.; Li, X.B.; Feng Z.J. Preparation, structure and mechanical properties of sialon ceramics by transition metalcatalyzed nitriding reaction. Rare Met. 2020, vol. 39 (5), pp. 589596.

[49] Riley, F.L. Silicon nitride and related materials. J. Am. Ceram. Soc. 2004, vol. 83 (2), pp. 245-265.

[50] Izhevskiy, V.A.; Genova, L.A.; Bressiani, J.C.; Aldinger, F. Progress in SiAlON ceramics. J. Eur. Ceram. Soc. 2000, vol. 20 (13), pp. 2275-2295.

[51] Jack, K.H. Review: sialon and related nitrogen ceramics. J. Mater. Sci. 1976, vol. 11, pp. 1135-1158.

[52] Zhuo T., Yuping Y., Yong W.,Haidong, W.; Wei, L.; Shanghua, W. The shrinkage, phase composition and mechanical properties of ceramics with different $\beta$-sialon main crystalline phases prepared by stereolithography. Ceramics Silikaty. 2020, vol. 64(2), pp.1-9.

[53] Yu, Z.B.; Thompson, D.P. Sialons. Ceramic-Matrix Composites. Microstructure. Properties and Applications. 2006, pp. 491-513. 
[54] Ekström, T. Effect of composition, phase content and microstructure on the performance of Yttrium-Si-Al-O-N ceramics. Mater. Sci. Eng. 1989, vol. A109, pp. 341-349.

[55] Mandal, H.; Kara, F.; Turan, S.; Kara, A. Novel SiAlON Ceramics for Cutting Tool Applications. Key Engineering Materials. 2003, vol. 237, pp. 193-202.

[56] Bitterlich, B.; Bitsch, S.; Friederich, K. SiAlON based ceramic cutting tools. Journal of the European Ceramic Society. 2008, vol. 28(5), pp. 989-994.

[57] Krebs, G.; Polli, M.L. Cutting Parameters for Roughing Turning of Alloy 625 Clad Using Ceramic Inserts. Materials Research. 2019; vol. 22(1): e20190535.

[58] Lima, Fábio F.; Sales, Wisley F.; Costa, Eder S.; da Silva, Flávio J.; Machado, Álisson R. (2016). Wear of ceramic tools when machining Inconel 751 using argon and oxygen as lubricooling atmospheres. Ceramics International. 2017, Vol. 43 (1), pp. 677-685.

[59] Zheng, G.; Zhao, J.; Song, X.; Cao, Q.; Li, Y. Ultra High Speed Turning of Inconel 718 with Sialon Ceramic Tools. Advanced Materials Research. 2010, vol. 126-128, pp. 653-657.

[60] Li, L.; He, N.; Wang, M.; Wang, Z.G. High speed cutting of Inconel 718 with coated carbide and ceramic inserts. Journal of materials processing technology. 2002, vol. 129 (127-130), pp. 127130.

[61] Nalbant, M.; Altin, A.; Gökkaya, H. The effect of cutting speed and cutting tool geometry on machinability properties of nickel-base Inconel 718 super alloys. Materials and Design. 2007, vol. 28(4), p. 1334-1338.

[62] Zheng, G.; Zhao, J.; Zhou, Y. Friction and wear behaviors of Sialon- $\mathrm{Si}_{3} \mathrm{~N}_{4}$ graded nano-composite ceramic materials in sliding wear tests and in cutting processes. Wear. 2012, vol. 290291, pp. 41-50.

[63] Shalaby, M.A.; Veldhuis, S. Effect of Cutting Speed on Chipping and Wear of the SiAlON Ceramic Tool in Dry Finish Turning of the Precipitation Hardenable IN100 Aerospace Superalloy. Journal of Tribology. 2018, vol. 141(2), 021604. 